\title{
Analysis Of Liquefaction Potential Based On Standart Penetration Test (SPT) In Puger, Jember, Indonesia
}

\author{
Alihudien $\mathrm{A}^{1}$, Suhartinah ${ }^{2}$, Warnana $\mathrm{DD}^{3}$ \\ \{ariefalihudien@unmuhjember.ac.id ${ }^{1}$, irtiens62@yahoo.co.id ${ }^{2}$,dwa_desa@geofisika.its.ac.id ${ }^{3}$ \} \\ Department of Civil Engineering, University of Muhammadiyah Jember, Jl. Karimata 49 Jember ${ }^{12}$ \\ Geophysics Department, Sepuluh Nopember Institute of Technology, Keputih -Sukolilo, Surabaya ${ }^{3}$
}

\begin{abstract}
Indonesia is an earthquake-prone area, this because Indonesia is in the world's largest plate meeting area. One of the problems caused by the earthquake is liquefaction. Liquefaction is the loss of soil shear strength of saturated sand due to earthquake loads. One simple method of liquefaction analysis is based on the results of the Standard Penetration test. This method was introduced by Youd, Idris and several other experts. In this study, will analyze the liquefaction potential in the area near the Puger coast, Jember, Indonesia. To carry out observation of liquefaction potential, 5 drill and SPT test points were used in several research locations. The result of this analysis is to use earthquake acceleration $0.34 \mathrm{~g}$. Liquefaction potential suspected at four drill points with different depth and thickness. If the security factor is averaged from 4 points that have the liquefaction potential, then FS from the result has value of 0.579 .
\end{abstract}

Keywords: liquefaction, puger, SPT.

\section{Introduction}

Puger is a sub-district of Jember Regency, East Java Province, Indonesia. This sub-district is very famous for its abundant sea products. The geographical coordinates are $8^{\circ} 22^{\prime} 0^{\prime \prime}$ South Latitude, $113^{\circ} 28^{\prime} 0^{\prime \prime}$ East Longitude. The Meteorology, Climatology and Geophysics Agency (BMKG) informed that on February 9, 2018 the seismic activity occurred in Puger (the coordinate points are at 8.90 South Latitude and 113.67 East Longitude) as an earthquake which is measured at 4.0 on the Richter Scale. This earthquake did not have the potential of a Tsunami wave. The epicentre was in the sea, precisely $81 \mathrm{~km}$ South West of Jember.

Because of this phenomenon, the impact of the earthquake needs to be considered, so we can reduce the impact. One of the impacts that might occur due to the earthquake is liquefaction. Concern for earthquake's impact can be done through mapping the liquefaction potential in Puger.

This study is a continuation from our previous study, which analyze about ground settlement due liquefaction in Puger. It was concluded that the catagory of degrees to building in Puger is a minor damage.

ICCSET 2018, October 25-26, Kudus, Indonesia

Copyright (C) 2018 EAI

DOI 10.4108/eai.24-10-2018.2280508 


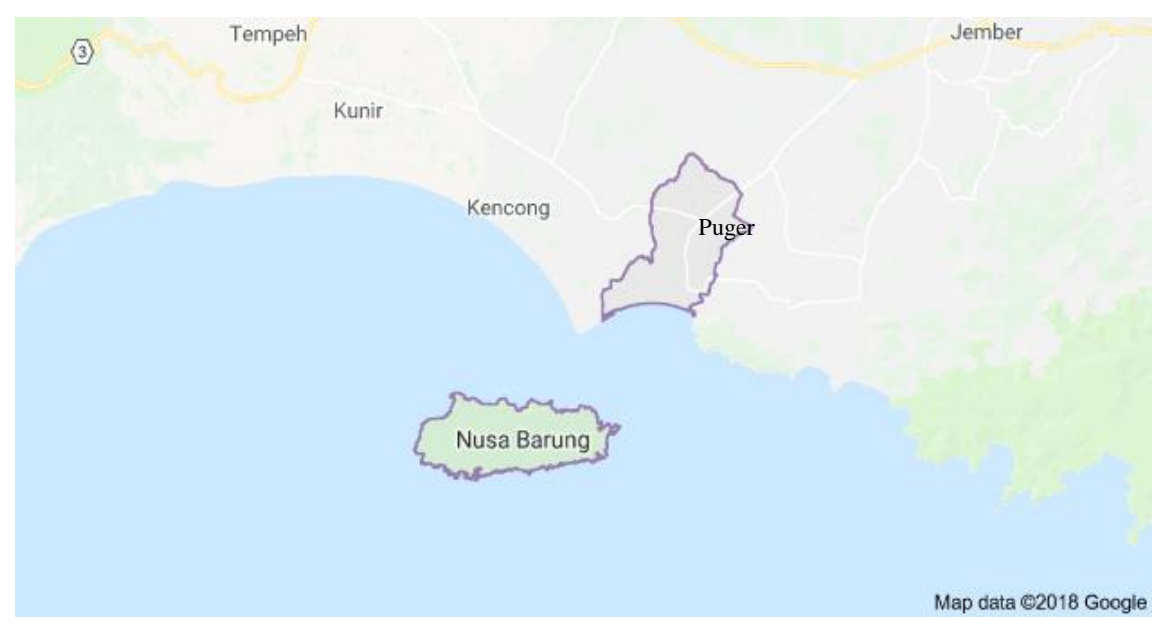

Fig. 1. Map of Puger Area, Jember, East Java.

\section{Liquefaction Potential Analysis Based on Standard Penetration Test}

The method used for liquefaction potential analysis is a method from a workshop called National Center for Earthquake Engineering Research (NCEER) in 1996 and 1998, chaired by Youd and Idriss. The workshop basically developed the basic "simplified procedure" (Seed and Idriss, 1971) [1] focused on analyzing soil resistance to liquefaction hazards, called Cyclic Resistance Ratio (Idriss and Boulanger, 2008) [2].

In an analysis of the potential for liquefaction, a grip value is needed to determine whether liquefaction occurs or not. This grip value is called a security factor. In the security factor analysis, values are needed which must be evaluated first. The value is the value of Cyclic Stress Ratio (CSR) and Cyclic Resistance Ratio (CRR) which are expressed in the form of the following equation (Youd and Idriss, 2001) [3]:

$$
F S=\frac{C R R_{7.5}}{C S R} M S F
$$

If FS $<1$, then the soil at that depth occurs liquefaction, if FS $=1$ then the soil is in critical condition, and if FS $>1$ then the soil does not experience liquefaction. According to Youd and Idriss (2001) [3] MSF is a Magnitude Scaling Factor whose value is sought from the following equation:

$$
M S F=10^{2.24} / M^{2.56}
$$

The calculation of CSR values uses the theory of several experts using the following equation (Seed and Idriss, 1971) [1]: 


$$
C S R=0.65\left(\frac{a_{\max }}{g}\right)\left(\frac{\sigma_{v o}}{\sigma_{v o}^{\prime}}\right) r_{d}
$$

Where $a_{\max }$ is the maximum ground acceleration due to an earthquake, $g$ is gravity acceleration $\sigma_{\mathrm{vo}}$ is the total vertical overburden stress, $\sigma_{\mathrm{vo}}^{\prime}$ is the vertical stress overburden, $\mathrm{r}_{\mathrm{d}}$ is the reduction voltage coefficient. The reduction voltage coefficient $\left(r_{d}\right)$ can be determined based on the equation (Liao and Whitemann, 1986) [4] as follows.

$$
\begin{aligned}
& r_{d}=1.00-0.00765 z \ldots \ldots z \leq 9.15 m \\
& r_{d}=1.174-0.0267 z \ldots . .15 \leq z \leq 23 m \\
& r_{d}=0.744-0.008 z \ldots \ldots .23 \leq z \leq 30 m \\
& r_{d}=0.5 z \ldots \ldots \ldots \ldots \ldots . . .2 \geq 23 m
\end{aligned}
$$

where $\mathrm{z}$ is the depth of soil $(\mathrm{m})$ reviewed.

As for how to analyze the value of Cyclic Resistance Ratio (CRR) from the Standard Penetration Test (SPT) as follows (Youd and Idriss, 2001) [3]

$$
\operatorname{CRR}_{7,5}=\frac{1}{34-\left(N_{1}\right)_{60 c s}}+\frac{\left(N_{1}\right)_{60 c s}}{135}+\frac{50}{\left\lceil 10\left(N_{1}\right)_{60 c s}+45\right\rceil}-\frac{1}{200}
$$

Youd and Idriss (2001) [3] and Cetin et al (2004) [5] provided corrections to obtain the value $\left(\mathrm{N}_{1}\right)_{60}$ as seen below:

$$
\left(\mathrm{N}_{1}\right)_{60}=\mathrm{N}_{\mathrm{m}} \mathrm{C}_{\mathrm{N}} \mathrm{C}_{\mathrm{E}} \mathrm{C}_{\mathrm{B}} \mathrm{C}_{\mathrm{R}} \mathrm{C}_{\mathrm{S}}
$$

Where Nm is the N-SPT obtained from the field test. $C_{N}$ is the normalization factor of $N_{m}$ against overburden stress in general. $C_{E}$ is a correction ratio of energy hammer $(E R) C_{B}$ is a correction for drill hole diameter $C_{R}$ is a correction factor of $C_{S}$ rod length is a correction for the sample. Due to an increase in the N-SPT value with increasing effective overburden stresses, overburden stress correction factors must be used (Seed and Idriss, 1982) [6]. This factor is generally calculated from the following equation (Seed and Idriss, 1982) [6].

$$
C_{N}=2.2 /\left(1.2+\frac{\sigma^{\prime}{ }_{v o}}{P a}\right)
$$

Where the $\mathrm{C}_{\mathrm{N}}$ value cannot higher than 1.7

Determination of the value $\left(\mathrm{N}_{1}\right)$ 60cs which is influenced by the value of Fines content itself (Youd and Idriss, 2001) [3].

$$
\left(N_{1}\right)_{60 c s}=\alpha+\beta\left(N_{1}\right)_{60}
$$

Where the values of $\alpha$ and $\beta$ are influenced by the percentage of content content (FC)

$$
\begin{array}{lr}
\alpha=0, \beta=1 & \mathrm{FC} \leq 5 \% \\
\alpha=\exp \left[1.76-\left(190 / \mathrm{FC}^{2}\right)\right] & 5 \%<\mathrm{FC}<35 \% \\
\beta=\left[0.99-\left(\mathrm{FC}^{1.5} / 1000\right)\right] & 5 \%<\mathrm{FC}<35 \% \\
\alpha=5, \beta=1.2 & \mathrm{FC} \geq 35 \%
\end{array}
$$


Table 1. Correction used in SPT (Youd \& Idriss, 2001) [3].

\begin{tabular}{llll}
\hline Factor & Tool Kind & Parameter & Corection \\
\hline Effective vertical stress & & $\mathrm{C}_{\mathrm{N}}$ & $2.2 /\left(1.2+\left(\sigma^{\prime}{ }_{\text {vo }} / \mathrm{Pa}\right)\right)$ \\
Effective vertical stress & & $\mathrm{C}_{\mathrm{N}}$ & $\mathrm{C}_{\mathrm{N}} \leq 1.7$ \\
Energy ratio & Donut hammer & $\mathrm{C}_{\mathrm{E}}$ & $0.5-1.0$ \\
Energy ratio & Safety hammer & $\mathrm{C}_{\mathrm{E}}$ & $0.7-1.2$ \\
Energy ratio & Automatic-trip Donut-type hammer & $\mathrm{C}_{\mathrm{E}}$ & $0.8-1.3$ \\
Bore diameter & $65-115 \mathrm{~mm}$ & $\mathrm{C}_{\mathrm{B}}$ & 1 \\
Bore diameter & $150 \mathrm{~mm}$ & $\mathrm{C}_{\mathrm{B}}$ & 1.05 \\
Bore diameter & $200 \mathrm{~mm}$ & $\mathrm{C}_{\mathrm{B}}$ & 1.15 \\
Bar length & $<3 \mathrm{~mm}$ & $\mathrm{C}_{\mathrm{R}}$ & 0.75 \\
Bar length & $3-4 \mathrm{~mm}$ & $\mathrm{C}_{\mathrm{R}}$ & 0.8 \\
Bar length & $4-6 \mathrm{~mm}$ & $\mathrm{C}_{\mathrm{R}}$ & 0.85 \\
Bar length & $6-10 \mathrm{~mm}$ & $\mathrm{C}_{\mathrm{R}}$ & 0.95 \\
Bar length & $10-30 \mathrm{~mm}$ & $\mathrm{C}_{\mathrm{R}}$ & 1 \\
Sampling & Standard tube & $\mathrm{C}_{\mathrm{S}}$ & 1 \\
Sampling & Liner tube & $\mathrm{C}_{\mathrm{S}}$ & $1.1-1.3$ \\
\hline
\end{tabular}

\section{Research Methodology}

The research methodology used in this study is an experimental method (Figure 2) by taking data in the field through drilling to be sampled and tested by Standard Penetration Test (SPT). In the implementation of this research 5 drill points (Figure 3) were taken at a certain distance, with a drill between 5 to $7 \mathrm{~m}$. then at each drill point the SPT test was carried out every $1 \mathrm{~m}$ depth. The disturbed samples obtained from split spoon tubes were taken and used to conduct laboratory tests in the form of sieve and hydrometer tests. The calculation of the potential for liquidation is carried out by looking for CRR and CSR, as well as by looking for FS values.

\section{Liquefaction Potential In Puger Based On SPT}

Puger based on The 2002 earthquake regulation catagorized as an earthquake area 4 and assumed as soft soil area, so the maximum earthquake acceleration on the surface is $\mathrm{a}_{\max }=$ $0.34 \mathrm{~g}$, for the MSF value is used 7.5 Richter Scale. While the depth of the water surface is adjusted to the conditions at the time of the drill test. At drill point 3 liquefaction potential occur within 1.5 - 3 meters with an average FS is 0.545 . At the drill point 1 liquefaction potential occur within $4-5$ meters with an average FS is 0.515 . At drill point 2 liquefaction potential occur within 1.5 - to 4.5 meters with an average FS of 0.737 . At drill point 4 liquefaction potential occur within $1.5-4.5$ meters with an average FS is 0.520 . At point 5 the liquefaction potential does not occur. 


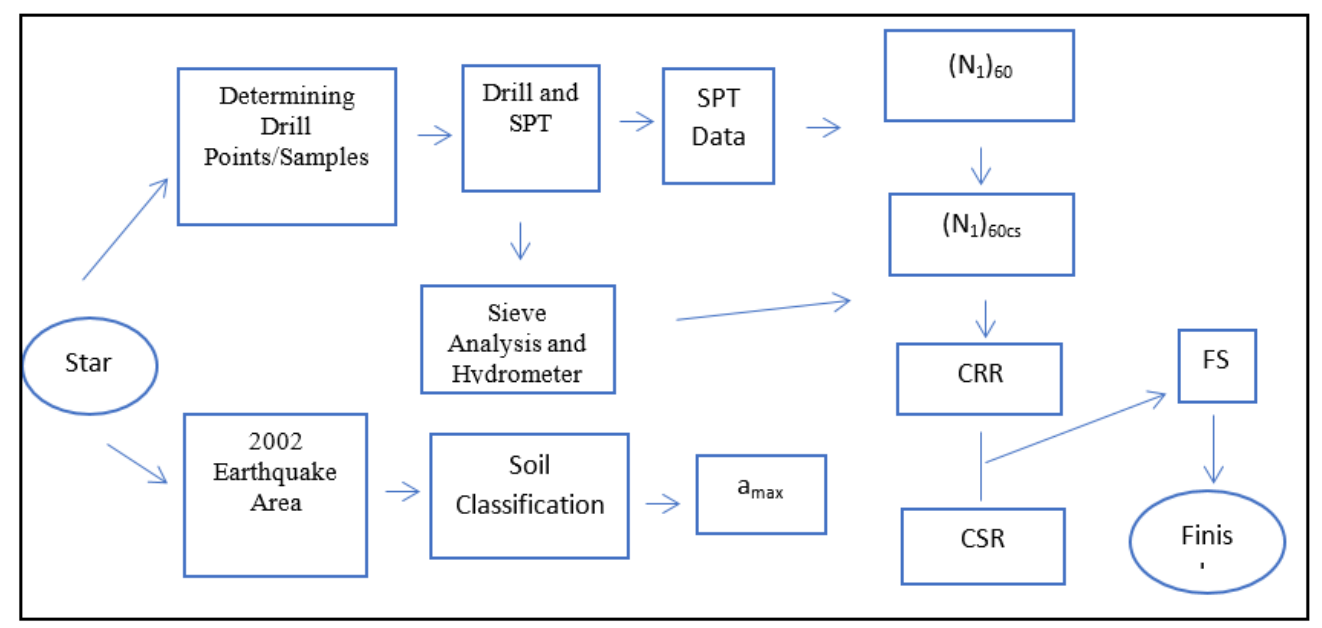

Fig. 2. Research Flow Chart.

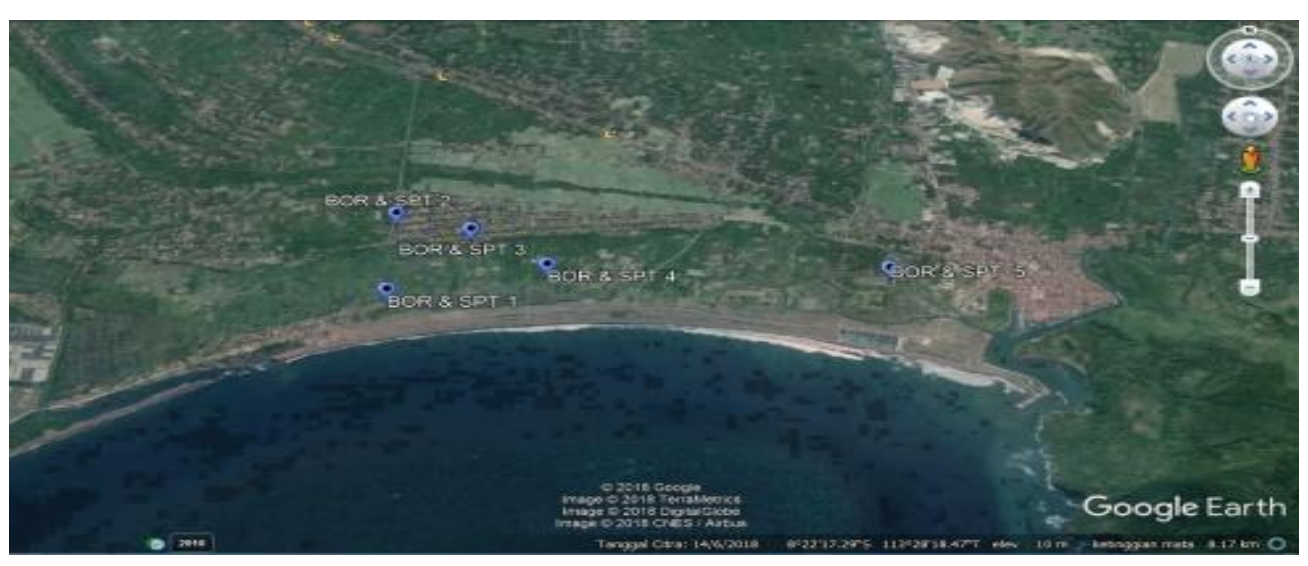

Fig. 3. Location of Bore Points and SPT. 


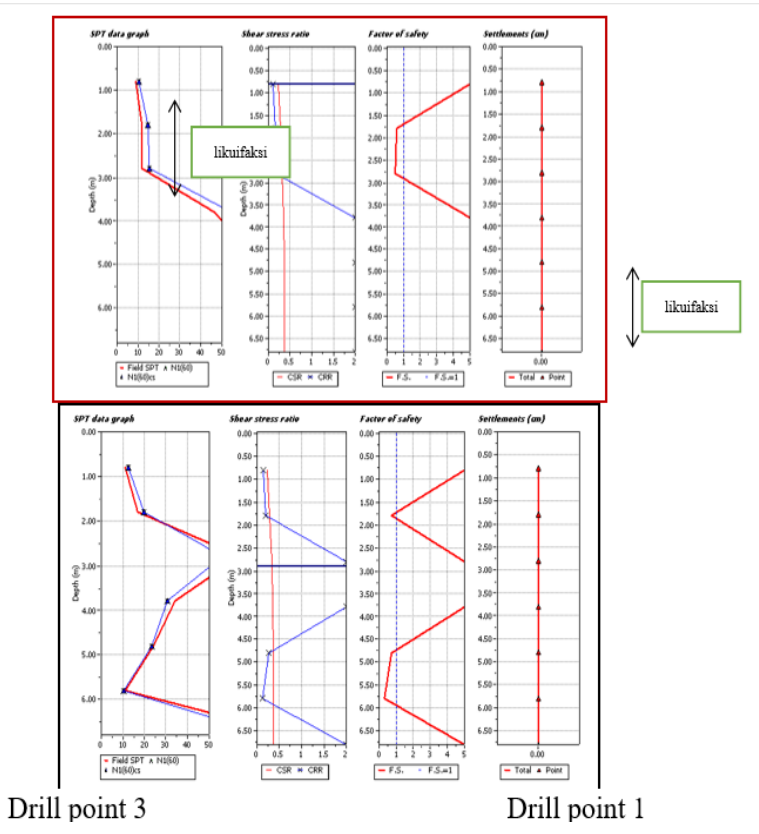

Fig. 4. Graph of relationship between N60, CRR and CSR, FS, and settlement with point 3 and 1.

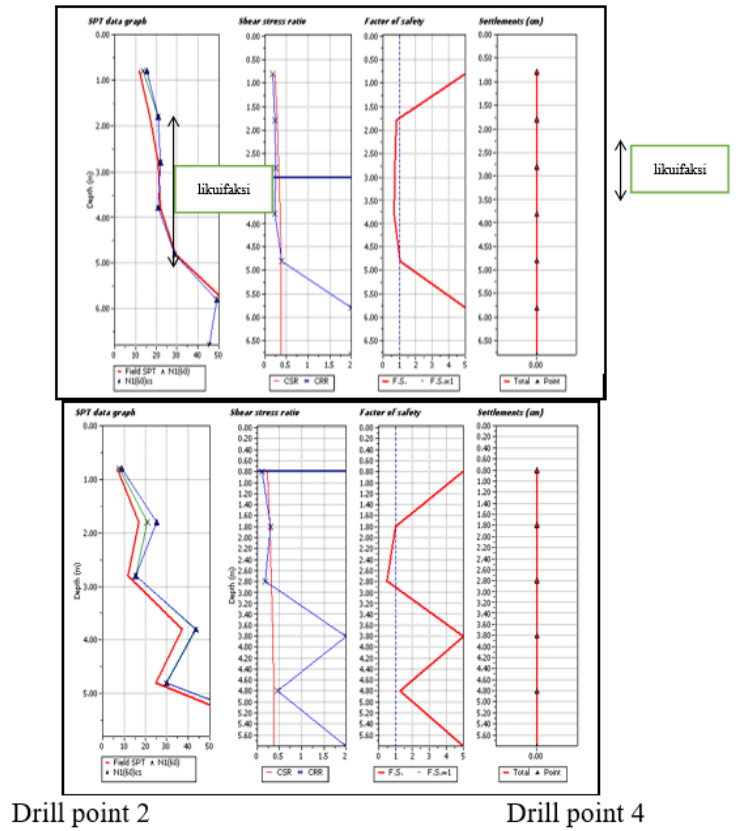

Fig. 5. Graph of relationship between N60, CRR and CSR, FS, and settlement with point 2 and 4 


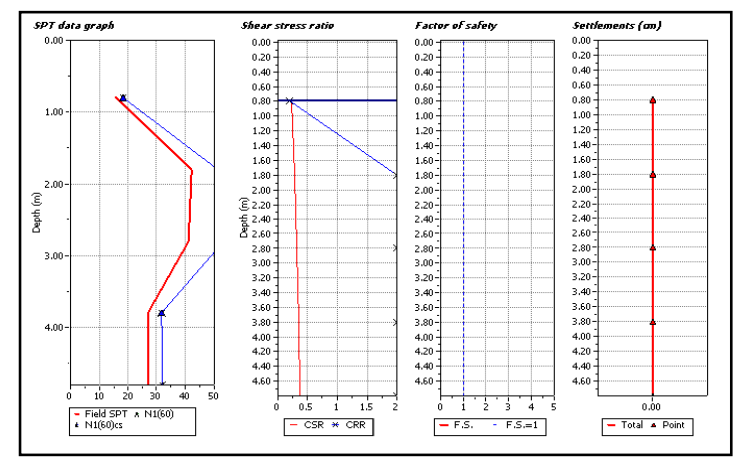

Drill point 5

Fig. 6. Graph of relationship between N60, CRR and CSR, FS, and settlement with point 5.

\section{Conclusion}

The conclusions in this study are as follows:

a) From the five drill points, it is found that the liquefaction potential occurs at four drill points (point 1, 2, 3, and 4), while at point 5 there is no liquefaction.

b) If the safety factor is averaged from 4 points with liquefaction potential, $\mathrm{FS}=0.579$ is obtained.

c) This research support our previous study about liquefaction in Puger focused on ground settlement analysis. From previous research, it's concluded that Puger has minor damage to building due to liquefaction.

d) In this study 5 drill points are still used, this data is relatively small, so to be able to give a clear picture of the research location it is necessary to add several more drill points so that a better picture is obtained about the liquidity potential of the research location.

\section{References}

[1] I. M. Seed, H.B. and Idriss, "Simplified Procedure for Evaluating Soil Liquefaction Potential," J. Soil Mech. Found. Div., pp. 1249-1273, 1971.

[2] R. W. Idriss, I.M. and Boulanger, "Soil Liquefaction during Earthquake," EERI Publ. Monogr. MNO-12, Earthq. Eng. Res. Inst., 2008.

[3] I. M. Youd, T.L., and Idriss, "Liquefaction Resistance of Soils: Summary Report from the 1996 NCEER and 1998 NCEER/NSF Workshops on Evaluation of Liquefaction Resistance of Soils," $J$. Geotech. Geoenvironmental Eng., pp. 297-313, 2001.

[4] R. V. Liao, S. S. C. and Whitman, "Overburden Correction Factors for SPT in Sand," J. Geotech. Geoenvironmental Eng., pp. 373-377, 1986.

[5] R. E. S. Cetin, K. O., Seed, R. B., Kiureghian, A. D., Tokimatsu, K., Harder, L. F., Jr., Kayen, R. E., and Moss, "Standard Penetration Test-Based Probabilistic and Deterministic Assessment of Seismic Soil Liquefaction Potential," J. Geotech. Geoenvironmental Eng., 2004.

[6] I. M. Seed, H. B. and Idriss, "Ground Motions and Soil Liquefaction during Earthquake," 1982. 